Tersedia Online di http://journal2.um.ac.id/index.php/jmsp/

ISSN Online : 2541-4429

\title{
SUPERVISI PEMBELAJARAN KEPALA MADRASAH DALAM MENINGKATKAN MUTU PEMBELAJARAN
}

\author{
Yumnan Abadi, Akhyak, Imam Fuadi \\ IAIN Tulungagung \\ Jl. Mayor Sujadi Timur 46 Tulungagung Jawa Timur Indonesia \\ yumnanabadi@gmail.com
}

\begin{abstract}
This study aims to gain an in-depth study of the supervision carried out by the headmaster. This study uses a qualitative approach, and the data collection techniques used are participant observation, in-depth interviews and documentation studies. This research was conducted in MAN 1 Trenggalek and MAN 2 Trenggalek, East Java. The results of this study that the head of the madrasa in carrying out supervision of learning adjusts to the plans outlined in the supervision program, uses instruments and observation sheets, uses the principles of supervision, uses techniques and approaches that are varied and carried out in a pleasant atmosphere. The head of the madrasa in order to carry out strategic steps as an embryo of success in implementing learning supervision in the madrasah.
\end{abstract}

Keywords: learning supervision, madrasah headmaster, learning quality

\begin{abstract}
Abstrak: Penelitian ini bertujuan untuk mendapatkan gambaran mendalam mengenai supervisi pembelajaran yang dilakukan oleh kepala madrasah. Penelitian ini menggunakan pendekatan kualitatif, dan teknik pengumpulan data yang digunakan adalah observasi partisipan, wawancara mendalam dan studi dokumentasi. Penelitian dilakukan di MAN 1 Trenggalek dan MAN 2 Trenggalek Jawa Timur. Hasil penelitian adalah kepala madrasah dalam melaksanakan supervisi pembelajaran menyesuaikan dengan rencana yang dituangkan dalam program supervisi, menggunakan instrumen dan lembar observasi, menggunakan prinsip-prinsip supervisi, menggunakan teknik dan pendekatan yang bervariasi dan dilaksanakan dengan suasana yang menyenangkan. Kepala madrasah agar melakukan langkah-langkah strategis sebagai embrio keberhasilan dalam pelaksanaan supervisi pembelajaran di madrasah.
\end{abstract}

Kata Kunci: supervisi pembelajaran, kepala madrasah, mutu pembelajaran

Saat ini, pendidikan memegang peranan penting dalam menentukan kualitas sumber daya manusia. Pada hakikatnya kualitas suatu bangsa dan negara tidak hanya ditandai dengan keindahan dan kekayaan alamnya, tetapi yang paling utama terletak pada keunggulan sumber daya manusia. Keunggulan sumber daya manusia tersebut berhubungan erat dengan mutu pendidikan. Mutu pendidikan sering ditandai dengan keadaan yang baik dan memenuhi syarat dalam segala komponen pendidikan yang meliputi proses, keluaran, tenaga kependidikan, sarana prasarana dan biaya. Sementara itu, mutu pendidikan tidak bisa lepas dengan adanya proses pendidikan dan pengajaran yang berlangsung pada suatu lembaga pendidikan yang menuntut upaya pengoordinasian secara sistematis dan terencana.

Hidayat dan Machali (2012:113) menyebutkan bahwa upaya ke arah ini salah satunya dapat terwujud dengan adanya pelaksanaan supervisi. Supervisi mempunyai peran penting dalam upaya peningkatan kompetensi dan kemampuan profesional guru. Supervisi tidak lain merupakan penerapan prinsip-prinsip demokrasi sehingga potensi manusia dapat berkembang secara kontinu baik dalam konteks kehidupan pribadi maupun bersama dan setiap orang dapat berpartisipasi dalam suatu komunitas masyarakat. Oleh karena 
itu, pengawasan atau supervisi merupakan bagian yang sangat penting dan tidak bisa dipisahkan dalam upaya peningkatan mutu pendidikan, baik yang ada di sekolah atau di madrasah.

Peningkatan mutu pendidikan merupakan tugas yang tidak mudah karena dipengaruhi oleh berbagai faktor seperti mutu masukan pendidikan, mutu sumber daya pendidikan, mutu guru dan pengelola pendidikan, mutu proses pembelajaran, kemampuan pengelola pendidikan dalam mengantisipasi dan menangani berbagai pengaruh lingkungan pendidikan. Ditinjau dari segi pendidikan, Makawimbang (2011:7273) menyebutkan supervisi diartikan dengan pembinaan yang diberikan kepada seluruh staf sekolah agar mereka dapat meningkatkan kemampuan untuk mengembangkan situasi belajar mengajar yang lebih baik. Menurut Sofyan dkk (2005:8-9) menjelaskan bahwa supervisi pembelajaran merupakan bagian yang tidak bisa dipisahkan dengan supervisi pendidikan. Secara substansial, supervisi pendidikan adalah suatu upaya yang dilakukan untuk meningkatkan mutu proses pendidikan yang dilaksanakan di sekolah/ madrasah, yang didukung dengan optimalisasi peran guru, ketersediaan sarana dan prasarana, desain kurikulum, sistem pembelajaran dan mekanisme penilaian dan pengukuran.

Menurut Purwanto (2014:76) supervisi mempunyai pengertian yang luas, yaitu segala bantuan dari para pemimpin sekolah yang tertuju kepada perkembangan kepemimpinan guru-guru dan personil sekolah lainnya di dalam mencapai tujuan-tujuan pendidikan. Pada prinsipnya, supervisi merupakan bimbingan dan bantuan kepada guru. Bantuan yang diberikan kepada guru harus berdasarkan penelitian atau pengamatan yang cermat dan penilaian yang objektif serta mendalam dengan acuan perencanan program pembelajaran yang telah dibuat. Proses bantuan yang diorientasikan pada upaya peningkatan kualitas proses dan hasil belajar itu penting sehingga bantuan yang diberikan benar-benar tepat sasaran. Jadi, bantuan yang diberikan oleh supervisor itu harus mampu memperbaiki dan mengembangkan situasi belajar mengajar. Sebagai pemimpin (leader), kepala sekolah/ madrasah berkewajiban untuk meningkatkan kinerja dan profesionalisme guru khususnya dalam melaksanakan proses pembelajaran yang efektif. Kepala sekolah/madrasah sebagai pemimpin pendidikan adalah menciptakan situasi proses pembelajaran sehingga para guru dapat mengajar dengan baik dan para siswa dapat belajar dengan baik pula. Dalam melaksanakan peran tersebut, kepala sekolah/ madrasah memiliki tanggung jawab ganda yaitu melaksanakan administrasi sekolah/madrasah sehingga tercipta situasi belajar mengajar yang baik dan melaksanakan supervisi sehingga para guru dapat meningkatkan mutu pengajaran serta mampu membimbing para siswanya.

Kinerja seorang guru dalam melaksanakan tugasnya sebagai pendidik dapat diidentifikasi dalam bentuk motivasi, komitmen, dan tanggung jawabnya dalam melaksanakan proses pembelajaran. Agar dapat menjalankan peran sebagai pemimpin, kepala sekolah/madrasah dituntut untuk memiliki kompetensi yang terdiri atas lima kompetensi. Hal ini sesuai dengan Peraturan Menteri Pendidikan Nasional Nomor 13 Tahun 2007 yang menetapkan bahwa kompetensi kepala sekolah meliputi : kompetensi kepribadian, kompetensi manajerial, kompetensi kewirausahaan, kompetensi supervisi dan kompetensi sosial. Secara lebih spesifik, kompetensi kepala madrasah dijelaskan pula dalam Peraturan Menteri Agama Republik Indonesia Nomor 58 Tahun 2017 yang menjelaskan bahwa kepala madrasah harus memiliki kompetensi: kepribadian, kompetensi manajerial, kompetensi kewirausahaan, kompetensi supervisi serta kompetensi sosial. Kompetensi kepala madrasah di atas adalah kriteria minimal yang berupa seperangkat pengetahuan, keterampilan, dan perilaku yang harus dimiliki oleh guru yang diberi tugas untuk memimpin dan mengelola satuan pendidikan formal yang menyelenggarakan pendidikan di lembaga pendidikan madrasah. Dalam melakukan inovasi dan mengembangkan kreativitas sesuai dengan tugas dan tanggung jawabnya sebagai supervisor, dibutuhkan sebuah kompetensi. Adanya kompetensi sangat mempengaruhi kelancaran dan ketercapaian tujuan pendidikan.

Suhardan (2010:840 menjelasjan bahwa supervisi dimaknai sebagai bantuan profesional berupaya memberdayakan dan pembinaan terus menerus untuk guru yang meliputi proses pembinaan guru dalam tugas profesionalnya (inservice professional development). Sementara menurut Glickman dan Gordon (1987:64) 
menyebutkan pada praktiknya seorang supervisor menyelaraskan bantuan kepada guru dengan tingkat konseptual guru utamanya bertujuan untuk memahamkan guru agar bertanggung jawab atas perbaikan (improvement) diri sendiri sehingga supervisi dapat memampukan guru dalam rangka belajar memperbaiki atau meningkatkan dirinya. Secara institusional menurut Burhanudin (2007:73) menjelaskan bahwa pengembangan dan peningkatan kompetensi, serta kinerja guru dapat dilakukan melalui upaya bantuan profesional yang memungkinkan guru tumbuh dan berkembang dan meningkatkan kemampuan profesionalnya serta belajar meningkatkan kepasitas profesionalnya yaitu berupa supervisi. Supervisi juga sebagai pembinaan profesional guru merupakan layanan yang digunakan secara bergantian dilihat dari dokumen kurikulum 1975, 1984 dan 1994 untuk sekolah dasar dan dokumen kurikulum 1994 untuk sekolah menengah umum. Pembinaan profesional dan supervisi tidak sama persis, tetapi berhubungan satu sama lain, demikian pula halnya dengan evaluasi. Pembinaan profesional dan evaluasi guru berbeda dengan supervisi pembelajaran (instruksional supervision) yaitu merupakan salah satu strategi pengembangan profesional guru dengan aktivitas peer-coaching, induksi, belajar kelompok, dan pengembangan portofolio.

Pentingnya supervisi pembelajaran tersebut juga tampak pada fenomena yang ada, bahwa pihak kementerian agama terus mengupayakan terwujudnya pelayanan pendidikan yang berkualitas terutama di lingkup madrasah, termasuk di dalamnya pelaksanaan supervisi pembelajaran yang dilakukan oleh kepala madrasah, wakil kepala madrasah, serta guru senior. Pelaksanaan supervisi pembelajaran diharapkan mampu: (1). meningkatkan kualitas dan profesionalisme guru dalam proses pembelajaran sehingga dengan proses pembelajaran yang baik akan meningkatkan mutu pendidikan; (2) memberdayakan tim pelaksana supervisi pembelajaran di madrasah yang meliputi: kepala madrasah, wakil kepala madrasah dan guru senior; (3) mengembangkan profesionalitas guru dengan memfokuskan pada kompetensi profesional dan kompetensi pedagogik; (4) mengaktifkan fungsi dan tanggung jawab serta kewenangan kepala madrasah sebagai pelaku supervisi di lembaga madrasah. Jadi, jelas secara keseluruhan supervisi merupakan tugas pokok dan tanggung jawab kepala madrasah.

Dengan demikian, supervisi merupakan suatu yang sangat penting dalam menjamin lembaga pendidikan melakukan layanan profesional. Proses supervisi pendidikan bukan lagi suatu yang hanya bersifat administratif, tetapi bersifat wajib (amanah) bagi pelaku supervisi (kepala sekolah/madrasah) dalam rangka memenuhi kebutuhan users yang membutuhkan pelayanan pendidikan yang multidisiplin, baik unsur akademik, administratif dan moral. Dalam teori ilmu administrasi, kepala sekolah/madrasah harus menguasai masalah administrasi baik di sekolah tingkat dasar, menengah, maupun pada sekolah tinggi. Monahan (1974:13) menyatakan dalam tulisannya, "Jika ada satu hal yang dapat dikatakan dengan beberapa pengertian tentang administrator pendidikan modern, apakah di sekolah dasar, sekolah menengah atau di sekolah tinggi".

Dalam proses manajemen, menurut Maunah (2009:2) supervisi berada dalam pengawasan "controlling". Oleh karena itu, suatu supervisi dalam sebuah organisasi pendidikan diperlukan sebagai alat yang dinamis serta mampu menjadi perangkat dasar seluruh komponen pendidikan menjalankan tugas dan tanggung jawab pelaku pendidikan sesuai dengan rencana dan tujuan yang telah ditetapkan. Begitu pentingnya peranan supervisor, maka kualitas dan eksistensinya harus diperhatikan, meskipun dalam beberapa fakta, pelaksanaan supervisi oleh kepala sekolah/madrasah sudah maksimal. Pemahaman semacam ini tidak benar untuk masa sekarang karena kepala sekolah/madrasah sebagai pucuk pimpinan dan penggerak serta penentu bagaimana lembaga pendidikan di madrasah lebih berkualitas. Kualitas sebuah sekolah/ madrasah ditentukan bagaimana kepala sekolah/ madrasah merumuskan visi, misi, dan tujuan yang akan dicapai. Sergovanni dkk (1987:126) menyatakan leadership activities associated with the cultural view include articulating school purposes and mission. Hal tersebut berarti bahwa kegiatan kepemimpinan kepala sekolah/ madrasah sangat berkaitan dengan proses dalam mengartikulasikan tujuan dan misi sekolah.

Kajian pada penelitian di atas menunjukkan bahwa supervisi pembelajaran sangat penting dan berguna untuk membantu guru berkembang 
secara profesional dan meningkatkan kualitas pembelajarannya sehingga berpengaruh positif terhadap prestasi belajar siswa. Hasil penelitianpenelitian tersebut menunjukkan masih adanya masalah-masalah supervisi yang memerlukan kajian lebih lanjut, yaitu: (1) kurangnya keterlibatan guru dalam semua proses supervisi, (2) kurangnya keterampilan kepala sekolah/ madrasah sebagai supervisor dan kurangnya keahlian dalam mata pelajaran yang disupervisi, (3) kepercayaan guru terhadap supervisor dan sikap administrator yang kurang positif terhadap kegiatan supervisi, (4) supervisi sebagai pengembangan kurang dilakukan, (5) masih adanya harapan bahwa supervisi akan membantu jika dilakukan dengan benar, serta (6) belum maksimalnya kegiatan supervisi oleh kepala madrasah pada tingkat menengah lanjutan. Bantuan terhadap guru untuk memampukan dirinya dan untuk belajar sepanjang hayat yang sejalan dengan perkembangan ilmu pengetahuan masih diperlukan. Sepanjang pengalaman peneliti selama bekerja di kantor kementerian agama menjadi pengawas pendidikan agama Islam maupun sebagai pengawas madrasah, peneliti menemukan unsur-unsur keterlibatan guru dan keterampilan kepala madrasah sebagai supervisor sangat menentukan keberhasilan dan efektivitas supervisi.

Berdasarkan fakta di atas, jelaslah bahwa peran kepala sekolah/madrasah sangat dominan dalam meningkatkan mutu pendidikan melalui kegiatan supervisi terutama dalam hal supervisi pembelajaran. Penelitian ini dilaksanakan dengan alasan bahwa berdasarkan pengamatan peneliti kedua lembaga tersebut mutunya sangat bagus dan selalu berprestasi dalam setiap kegiatan di tingkat kabupaten, provinsi maupun nasional baik prestasi dalam bidang akademik maupun non akademik. Hal ini dapat dilihat dari meningkatnya perkembangan jumlah siswa yang terjadi pada setiap tahunnya. Dari sisi proses pembelajarannya yang baik, perkembangan siswanya cukup pesat sehingga peneliti ingin mengetahui lebih jauh dan lebih dalam dari sisi kegiatan dan proses pembelajarannya terutama dalam kegiatan supervisi pembelajaran yang dilakukan oleh kepala madrasah. Peneliti berpedoman bahwa kemajuan sebuah lembaga pendidikan terletak pada mutu pendidikan.
Selain itu, mutu pendidikan tidak terlepas dari proses pembelajaran di madrasah dan proses pembelajaran yang baik tidak terlepas dari pelaksanaan supervisi yang dilakukan oleh kepala madrasah.

\section{METODE}

Pendekatan yang peneliti lakukan adalah sesuai dengan konsep penelitian kualitatif. Menurut Tanzeh (2011:64) yakni penelitian yang dimaksudkan untuk mengungkap gejala holistik-kontekstual melalui pengumpulan data dari latar alami sebagai sumber langsung dengan instrumen kunci peneliti itu sendiri. Dengan kata lain, menurut Bogdan dan Biklen (1982:14) penelitian ini bersifat deskriptif, maknawi, dan tidak terfokus pada kuantitas data sehingga penelitian yang sesuai adalah dengan pendekatan kualitatif. Penelitian ini bertujuan untuk mendapatkan gambaran mendalam mengenai supervisi pembelajaran yang dilakukan oleh kepala madrasah di kedua lembaga tersebut, yang meliputi aspek pernecanaan supervisi pembelajaran, pelaksanaan supervisi pembelajaran dan evaluasi supervisi pembelajaran dalam meningkatkan mutu pembelajaran.

Dalam penelitian ini, kondisi kedua madrasah yang berjauhan memiliki karakteristik yang berbeda, tetapi memiliki kasus yang serupa. Penelusuran fenomena berfokus kepada aktifitas supervisi pembelajaran di MAN 1 Trenggalek dan MAN 2 Trenggalek yang supervisi pembelajaran melibatkan kepala madrasah, wakil kepala madrasah, dan guru senior. Jenis penelitian yang digunakan adalah penelitian lapangan (field reasearch) dengan menggunakan rancangan multisitus, yaitu subjek yang diteliti adalah MAN 1 Trenggalek dan MAN 2 Trenggalek. Sekalipun kedua Madrasah Aliyah Negeri ini memiliki karakteristik yang berbeda, tetapi keduanya menerapkan supervisi pembelajaran yang serupa. 


\section{HASIL DAN PEMBAHASAN}

\section{Perencanaan supervisi pembelajaran}

Perencanaan supervisi pembelajaran yaitu menentukan kegiatan-kegiatan yang akan dilaksanakan dalam pelaksanaan supervisi pembelajaran. Perencanaan adalah suatu hal yang sangat penting dalam mencapai suatu tujuan. Tujuan diadakan supervisi dimaksudkan sebagai usaha untuk mendorong para guru untuk mengembangkan kompetensinya agar dapat mencapai tujuan yang lebih baik. Perencanaan supervisi pembelajaran harus dibuat sebagai pedoman dalam melaksanakan tugas agar tujuan pendidikan tercapai sesuai dengan yang diharapkan. Perencanaan (planning) adalah proses menuju tercapainya tujuan tertentu atau dalam istilah lain merupakan persiapan yang terarah dan sistematis agar tujuan dapat dicapai secara efektif dan efisien.

Menurut Terry (2003:46) perencanaan merupakan memilih dan menghubungkan fakta menggunakan asumsi-asumsi tentang masa depan dalam membuat visualisasi dan perumusan kegiatan yang diusulkan. Hal ini memang diperlukan untuk mendapat hasil yang diinginkan. Sedangkan Allen (2005:42) menyebutkan bahwa perencanaan terdiri atas aktivitas yang diatur oleh suatu manajer untuk berpikir ke depan dan mengambil keputusan. Aktivitas perencanaan yang dimaksud disini yaitu Prakiraan (forecasting), penetapan tujuan (establisting objective) dan pemrogaman (programming). Suatu perencanaan adalah aktivitas integratif yang berusaha memaksimumkan efektivitas seluruhnya dari suatu organisasi sebagai suatu sistem, sesuai dengan tujuan yang ingin dicapai. Berdasarkan definisi tersebut, perencanaan minimal harus memiliki tiga karakteristik berikut, yaitu masa yang akan datang, tindakan dan indentifikasi pribadi, serta organisasi.

Perencanaan pembelajaran merupakan proses terpenting dalam pelaksanaan supervisi pembelajaran untuk mencapai tujuan. Semua fungsi manajemen tanpa perencanaan maka fungsi-fungsi yang lain seperti pengorganisasian, pengarahan, dan pengontrolan tidak akan berjalan dengan baik. Sofyan (2005:8-9) menyebutkan perencanaan merupakan memilih dan menghubungkan fakta menggunakan asumsi-asumsi tentang masa depan dalam membuat visualisasi dan perumusan kegiatan yang diusulkan. Hal ini memang diperlukan untuk mendapat hasil yang diinginkan. Ketersediaan sarana dan prasarana, desain kurikulum, sistem pembelajaran dan mekanisme penilaian dan pengukuran.

Dalam perencanaan supervisi pembelajaran, pembuatan program supervisi merupakan langkah yang tepat bagi kepala madrasah untuk menyusun strategi dalam kegiatan supervisi. Program supervisi bertujuan: (1) sebagai acuan bagi pelaksanaan kegiatan supervisi; (2) meningkatkan profesionalisme guru dalam melaksanakan tugas pokok dan fungsinya sebagai pendidik; (3) meningkatkan kualitas proses pembelajaran pada setiap mata pelajaran yang bermuara pada peningkatan kualitas tamatan; (4) di samping itu, selain supervisi akademis, program supervisi ini juga dilengkapi dengan supervisi manajerial pada setiap unit kegiatan yang merupakan supervisi internal dalam rangka meningkatkan kualitas pengelolaan unit kegiatan dan administrasi sekolah/ madrasah.

Secara teknis langkah berikutnya yang dilakukan kepala madrasah dalam perencanaan supervisi pembelajaran adalah menyiapkan instrumen-instrumen yang akan digunakan dalam melaksanakan supervisi. Perencanaan supervisi pembelajaran yang disusun meliputi program kerja, program supervisi yang di dalamnya terdapat instrumen-instrumen sabagai alat ukur. Dari penjelasan di atas jelas sudah bahwa Kepala Madrasah melakukan perencanaan supervisi dengan menyusun instrumen supervisi pembelajaran dalam rangka standar ukuran 
hasil yang diperoleh guru.

\section{Pelaksanaan Supervisi Pembelajaran}

Kepala madrasah melaksanakan kegiatan supervisi disesuaikan dengan rencana yang telah dituangkan dalam program supervisi kepala madrasah. Hal ini berupa dokumen pelaksanaan supervisi pembelajaran. Pelaksanaan supervisi pembelajaran selain dilakukan oleh kepala madrasah juga dilakukan oleh pengawas madrasah. Hal ini dilakukan sebanyak dua kali dalam setiap semester. Dalam melaksanakan perannya sebagai supervisor kepala madrasah harus tahu dan paham serta menguasai tentang prinsip-prinsip dan teknik-teknik supervisi agar pelaksanaannya berjalan sesuai dengan tujuan supervisi. Dalam Peraturan Menteri Agama Republik Indonesia Nomor 58 Tahun 2017 dijelaskan bahwa kepala madrasah melaksanakan tugas manajerial, mengembangkan kewirausahaan dan melakukan supervisi kepada guru dan tenaga kependidikan. Sementara kompetensi yang harus dimiliki oleh kepala madrasah berdasarkan Peraturan Menteri Pendidikan Nasional Nomor 13 Tahun 2007 tentang Standar Kepala Sekolah/Madrasah terdiri dari 5 kompetensi di antaranya kompetensi manajerial, kompetensi kewirausahaan, kompetensi supervisi, kompetensi kepribadian, dan kompetensi sosial. Hidayat dan Machali (2012:13) menjelaskan Supervisi pembelajaran mempunyai peran penting dalam upaya peningkatan kompetensi dan kemampuan profesional guru. Berikut ini adalah bagan hubungan antara supervisi pendidikan, perilaku mengajar, perilaku belajar, dan hasil belajar.

Supervisi pembelajaran menurut Purwanto (2014:120) dapat dilaksanakan dengan berbagai cara, dengan tujuan agar apa yang diharapkan bersama dapat menjadi kenyataan. Secara garis besarcara atau teknik supervisi dapat digolongkan menjadi dua, yaitu teknik perseorangan dan teknik kelompok. Adapun prinsip-prinsip supervisi menurut Daryanto dan Rachmawati (2015:147-148) di antaranya: prinsip ilmiah, demokratis, kerja sama, konstruktif dan kreatif. Dalam kegiatan supervisi kepala madrasah menggunakan prinsip-prinsip supervisi dan pendekatan sebagaimana dijelaskan di atas. Sedangkan tentang pendekatan dan metode yang digunakan adalah teknik dan pendekatan yang bervariasi serta dilaksanakan dalam suasana yang menyenangkan. Hal ini sebagaimana dijelaskan di dalam prinsip-prinsip supervisi yaitu prinsip demokratis dapat diartikan bahwa bantuan yang diberikan kepada guru berdasarkan hubungan kemanusiaan yang akrab, sehingga guru merasa aman untuk mengembangkan tugasnya. Sedangkan, di MAN 2 Trenggalek, kepala madrasah menggunakan prinsip dan pendekatan supervisi yaitu dengan melakukan pembinaan kepada guru secara intensif, pendekatan individual dan metode pemecahan masalah, serta melakukan invovasi dalam proses supervisi pembelajaran.

Secara lebih rinci beberapa rumusan tentang langkah-langkah dalam pelaksanaan supervisi pembelajaran yang dilakukan kepala madrasah adalah (1) pemberitahuan dan pembuatan jadwal supervisi; (2) pengecekan langsung terhadap perangkat pembelajaran; (3) melakukan supervisi kunjungan kelas, (4) evaluasi dan tindak lanjut dari pelaksanaan supervisi; (5) menyusun kurikulum sesuai dengan kebutuhan masyarakat; (6) melakukan inovasi pendekatan dan metode supervisi; (7) memberikan layanan internet gratis kepada guru; dan (8) melakukan pembimbingan dan pendampingan kepada guru secara berkelanjutan.

Pelaksanaan supervisi pembelajaran kepala sekolah/madrasah tidak terlepas dari pendekatan dan teknik supervisi yang sudah dibahas dalam penjelasan di awal. Untuk mencapai tujuan supervisi yang telah ditentukan, maka seorang supervisor dapat menggunakan berbagai macam teknik. Sahertian mengelompokkan teknik supervisi menjadi dua macam, yaitu teknik individual dan teknik kelompok. Teknik individual meliputi ; kunjungan kelas, observasi kelas, percakapan pribadi, intervisitasi dan menilai diri sendiri. Teknik bersifat kelompok meliputi ; (1). pertemuan orientasi pada guruguru; (2) panitia penyelenggara; (3) rapat guru; (4) studi kelompok; (5) diskusi; (6) tukar-menukar pengalaman; (7); lokakarya (workshop); (8) simposium; (9) demonstrasi mengajar; (10) perpustakaan jabatan; dan (11) perjalanan sekolah untuk anggota staf.

Pelaksanaan supervisi pembelajaran juga menggunakan teknik individual dan teknik kelompok. Hal ini dapat dilihat dengan kegiatan supervisi yang sudah dilaksanakan oleh kepala madrasah. Dengan demikian teknik supervisi 
sangat penting untuk dikuasai oleh kepala sekolah. Tanpa penguasaan teknik ini, dalam pelaksanaanya tidak akan berjalan baik. Teknik supervisi akan lebih memudahkan pencapaian sasaran-sasaran dari tujuan yang telah ditetapkan. Oleh sebab itu, penerapan teknik dari supervisi merupakan wujud dari kemajuan sekolah untuk berkembang. Dalam pelaksanaannya, supervisi pembelajaran akan meningkatkan proses pembelajaran jika dilakukan dengan menggunakan prinsip-prinsip dan pendekatan yang berlaku. Oleh karena itu, sebagai seorang supervisor harus mengetahui terlebih dahulu peran dan fungsinya sebagai orang yang dapat menolong dan memberikan bantuan kepada guru dalam meningkatkan proses pembelajaran di madrasah. Proses pelaksanaan program supervisi pembelajaran dapat dilakukan secara konsekuen. Jadi pelaksanaan program ini dipastikan bisa memperbaiki proses pembelajaran yang dilaksanakan pada saat ini oleh guru. Tujuanya yaitu dari kurang efektif akan menjadi lebih efektif, dari kurang bermakna akan menjadi lebih bermakna.

\section{Evaluasi Supervisi Pembelajaran}

Evaluasi supervisi pembelajaran ini dilakukan dengan cara merefleksi pembelajaran yang telah dilaksanakan, refleksi dilakukan guru bersama supervisor/kepala madrasah. Hasil dari tahap refleksi dicatat dan akan dipakai sebagai bahan untuk melakukan tindak lanjut. Namun dalam praktiknya, masih sering belum dilaksanakan. Dari catatan hal-hal yang ditemukan, tidak dilanjutkan dengan diskusi dan hanya merupakan catatan tanpa ada tindak lanjut. Evaluasi program supervisi pembelajaran adalah pemberian estimasi terhadap pelaksanaan supervisi pembelajaran untuk menentukan keefektifan dan kemajuan dalam rangka mencapai tujuan supervisi pembelajaran yang telah ditetapkan. Dalam evaluasi program supervisi pembelajaran, perbaikan pengajaran melibatkan unsur dalam penentuan perubahan yang terjadi pada periode tertentu. Perubahan yang diharapkan dari semua personel dalam supervisi dan dalam perbaikan program melibatkan kepala sekolah (supervisor), guru, dan murid. Supervisor dan guru bekerja sama untuk membawa perubahan-perubahan dalam diri peserta didik. Di samping itu, beberapa hal yang harus dipertimbangkan sebagai upaya evaluasi adalah masalah ruang lingkup supervisi pembelajaran yang meliputi rencana perbaikan, organisasi perencanaan, tujuan yang akan dicapai, teknik-teknik pencapaian tujuan supervisi, dan perubahan-perubahan yang dilakukan di bidang kurikulum dan bimbingan.

Evaluasi program supervisi pembelajaran tidak berarti mengevaluasi suatu rancangan pembelajaran berusaha menentukan sampai seberapa jauh tujuan supervisi pendidikan yang telah tercapai. Oleh sebab itu, bukan saja programnya yang dievaluasi, tetapi juga proses pelaksanaan dan hasil supervisi pendidikan. Bahkan, ruang lingkup evaluasi supervisi pendidikan menyangkut semua komponen yang terkait dalam pelaksanaan supervisi pendidikan. Komponen tersebut meliputi aspek personel, aspek material, dan aspek operasional dalam supervisi pembelajaran. Setiap aktivitas yang dilakukan oleh manusia sudah pasti memiliki tujuan tertentu karena aktivitas yang tidak mempunyai tujuan berarti merupakan aktivitas atau pekerjaan yang sia-sia.

Kegiatan evaluasi pembinaan yang dilakukan oleh kepala madrasah berdasarkan catatan-catatan pada format kunjungan kelas dan pelaksanaan observasi kepada para guru. Hal ini dimaksudkan sebagai bahan untuk melakukan analisis dan masukan dalam membuat program pembinaan kepada para guru untuk langkah berikutnya. Kepala madrasah melakukan evaluasi di setiap kegiatan dan menyusun Rencana Tindak Lanjut (RTL). Adanya kegiatan tindak lanjut dari kepala madrasah dengan diberikannya kesempatan kepada guru untuk ikut aktif dalam kegiatan MGMP seperti yang dijelaskan di atas pada bagian pelaksanaan supervisi pembelajaran.

Dalam melaksanakan evaluasi, kepala madrasah sebagai evaluator pada tahap awal harus menentukan fokus yang akan dievaluasi dan desain yang akan digunakan. Lebih lanjut, Brikerhoff dalam Mardapi (2000:2) mengemukakan bahwa pelaksanaan evaluasi terhadap tujuh elemen yang harus dilakukan, yaitu (1) focusing the evaluation (penentuan fokus yang akan dievaluasi); (2) designing evaluation (penyusunan desain evaluasi); (3) collecting information (pengumpulan informasi); (4) analizing and interpreting (analisis dan interpretasi informasi); (5) reporting information 
(pembuatan laporan); (6) managing evaluation (pengelolaan informasi); dan (7) evaluating evaluation (evaluasi untuk evaluasi).

Kepala madrasah melaksanakan kegiatan evaluasi berdasarkan catatan-catatan pada format kunjungan kelas kepada para guru untuk setiap tahunnya. Hal ini dimaksudkan untuk dijadikan bahan analisis dan masukan dalam membuat program pembinaan kepada para guru di tahun berikutnya untuk pelaksanaan tindak lanjut. Pada tahapan tindak lanjut hasil pengamatan didiskusikan secara terbuka antara kepala madrasah dengan guru. Hal lain dalam bahasan evaluasi supervisi pembelajaran adalah kepala madrasah menyusun laporan hasil supervisi, menganalisis, mengolah data dan memecahkan masalah. Secara lebih seksama, hal tersebut untuk kepentingan proses pembelajaran yang dilaksanakan di kelas. Salah satu kinerja kepala madrasah yang tidak boleh diabaikan dan merupakan kewajiban dari setiap kepala madrasah adalah memberikan laporan tertulis kepada atasannya, yaitu pengawas pembina dan kantor Kementerian Agama Kabupaten Trenggalek. Pemberian laporan merupakan kontrol oleh satuan atasan kepda pegawas yang telah melaksakan tugas secara periodik. Pemberian laporan merupakan bukti autentik yang bersifat transparan terhadap seluruh tugas yang telah dilaksanakan. Laporan kegiatan dibuat bulanan dan perlu dibuat agar program kerja dapat terkontrol sekaligus sebagai pertanggungjawaban dari setiap pengawas dalam melaksanakan tugasnya. Dengan adanya laporan pertanggungjawaban pelaksanaan program maka dapat diketahui implikasi dari kinerja kepala madrasah, apakah bermanfaat bagi guru, madrasah, guru dan manajemen madrasah serta pencapaian tujuan pendidikan.

Berdasarkan paparan di atas, dapat disimpulkan bahwa kegiatan supervisi yang dilaksanakan oleh kepala madrasah kepada guru dalam proses pembelajaran merupakan tugas dan tanggung jawabnya dalam menyelenggarakan pendidikan di sekolahnya. Oleh karena itu, kegiatan supervisi harus dapat dilaksanakan secara tepat dan efektif sehingga dengan pelaksanaan supervisi yang efektif akan dapat membantu para guru dalam proses kegiatan pembelajaran di madrasah.

\section{SIMPULAN}

Upaya peningkatan mutu pembelajaran dengan mengacu dari tugas pokok dan kompetensi kepala madrasah yaitu melaksanakan supervisi pembelajaran. Langkah awal yang dilakukan oleh kepala madrasah adalah merencanakan supervisi pembelajaran dalam bentuk rancangan yang tertuang di dalam program kerja dan program supervisi kepala madrasah. Kepala madrasah mempunyai tugas yang tidak ringan dalam mengkondisikan para gurunya dalam menyiapkan proses pembelajaran. Posisi kepala madrasah dalam hal supervisi sangatlah menentukan dalam meningkatkan kualitas pembelajaran di kelas dan peningkatan pembelajaran sangat berhubungan dengan kualitas kinerja dan profesionalisme guru.

Dalam hal pelaksanaannya kepala madrasah harus melaksanakan supervisi minimal 1 kali dalam satu semester, hal ini dimaksudkan karena tugas kepala madrasah saat ini terfokus pada kegiatan memenej lembaga yang dipimpinnya. Proses yang harus dilalui oleh kepala madrasah adalah mulai dari perencanaan supervisi pelaksanaan supervisi maupun evaluasi supervisi. Berdasarkan dari alur tugas kepala madrasah tersebut diharapkan pelaksanaan mutu pembelajaran dapat dicapai dengan baik. Kegiatan supervisi pembelajaran difokuskan kepada guru dalam pembelajaran agar mutu dari siswa menjadi lebih baik. Dampak langsung dari proses tersebut guru dapat meningkat kompetensinya, utamanya kompetensi profesionalnya.

\section{DAFTAR RUJUKAN}

ASofyan, A. dkk. 2005. Peningkatan Supervisi dan Evaluasi pada Madrasah ibtidaiyah. Jakarta : Departemen Agama RI Dirjen Kelembagaan Agama Islam.

Tanzeh, A. 2011. Metodologi Penelitian Praktis. Yogyakarta: Teras.

Hidayat, A \& Machali, I. 2012. Pengelolaan Pendidikan. Yogyakarta: Kaukaba.

Maunah, B. 2009. Supervisi Pendidikan Islam Teori dan Praktik. Yogyakarta: Teras.

Bogdan \& Biklen, 1982. Qualitative Research for Education: An Introduction to Theory and Methods. London: Allyn and Bacon, In.

Burhanudin, 2007. Supervisi dalam Rangka Pembinaan Profesional. Malang : FIP UM. 
Suhardan, D. 2010. Supervisi Profesional : Layanan dalam Meningkatkan Mutu Pembelajaran di Era Otonomi Daerah. Bandung: Alfabeta.

Daryanto \& Rachmawati, R. 2015. Supervisi Pembelajaran Inspeksi meliputi: Controlling, Correcting, Judging, Directing, Demonstration. Yogyakarta: Gava Media.

Terry, G.R. 2003. Prinsip-prinsip Manajemen. Bandung: Bumi Aksara.

Makawimbang. 2011. Supervisi dan Peningkatan Mutu Pendidikan. Bandung : Alfabeta.

Purwanto, N. 2014. Administrasi dan Supervisi Pendidikan. Bandung : PT. Remaja Rosdakarya.
Peraturan Menteri Agama Republik Indonesia Nomor 58 Tahun 2017 tentang Kompetensi Kepala Madrasah.

Peraturan Menteri Pendidikan Nasional Republik Indonesia Nomor 13 Tahun 2007 tentang Standar kepala Sekolah/Madrasah.

Sahertian, P.A. 2008. Konsep Dasar \& Teknik Supervisi Pendidikan Dalam Rangka Pengembagan Sumber Daya Manusia. Jakarta: Rineka Cipta.

Zulkarnain, W. 2018. Manajemen Layanan Khusus di Sekolah. Jakarta: Bumi Aksara. 